\title{
New MTCYB Haplotypes in Romanian Buffalo
}

\author{
Cristian-Ovidiu COROIAN ${ }^{1)}$, Aurelia COROIAN ${ }^{1) *}$, Vioara MIREȘAN ${ }^{1) *}$, Mihai ŞUTEU ${ }^{1)}$, Călin LAȚIU ${ }^{1)}$, \\ Camelia RĂDUCU ${ }^{1)}$ \\ 1)Faculty of Animal Science and Biotechnologies, University of Agricultural Sciences and Veterinary \\ Medicine, 400372 Cluj-Napoca, Mănăştur Street 3-5, Romania \\ *Corresponding authors, e-mail: coroian.aurelia@gmail.com, vmiresan@yahoo.com
}

Bulletin UASVM Animal Science and Biotechnologies 72(2) / 2015

Print ISSN 1843-5262; Electronic ISSN 1843-536X

DOI:10.15835/buasvmcn-asb:11552

\begin{abstract}
The Romanian Buffalo Breed (RBB), established in 1987, originated from local river buffalo populations highly adapted to the low-input breeding condition. Cross-breeding with Asian breeds was recently used for genetic improvement in milk production. In the last 25 years the species has dramatically decreased. Over $90 \%$ of livestock has been sold and never replaced. The population is now mainly maintained in subsistence farms. This study aims to assess the genetic diversity within the remaining population and to verify links with improved breeds supposedly introgressed in RBB. To assess the genetic diversity of RBB and ascertain possible phylogenetic relations with other buffalo breeds, we sequenced the entire cytochrome B gene (MTCYB) in a sample population. Blood samples were collected from randomly selected 52 unrelated individuals from various locations in Transylvania. A DNA fragment containing the entire MTCYB gene $(1140 \mathrm{bp})$ was amplified by PCR directly from whole blood $(1 \mu \mathrm{l})$. The amplicons were sequenced using two pairs of primers. The sequences were subsequently used for genetic diversity assessments. Analysis of the sequences led to the identification of five novel MTCYB haplotypes, uploaded in GenBank with the following accession numbers: JQ241279; JQ241280; JQ241281; JQ241282; JQ241283. In the sample population, the most frequently identified haplotypes were haplotype 2 (EF409940.1) and haplotype 3 (EF409941.1), previously reported in other buffalo populations, mainly from Asia, confirming the Asiatic origins of RBB. Sequence comparisons have revealed that RBB is mainly related with Indian breeds. Despite the numerical decline of RBB, through correct breeding schemes the breed maintained a good level of genetic diversity. Our analysis confirms RBB's Asiatic origins. Presence of new haplotypes may also reflect that this population is isolated from a geographical and reproductive point of view.
\end{abstract}

Keywords: buffalo, genetic diversity, MTCYB haplotypes.

\section{INTRODUCTION}

Water buffaloes (Bubalus bubalis) originated from Asia and migrated after domestication in many parts of the world. Water buffalo is broadly classified into river and swamp categories, and it appears that the Indian water buffalo supports a distinct genetic origin of river and swamp buffalo (Kumar et al., 2007) based on mitochondrial DNA analyses. High genetic variation between domestic swamp buffaloes from China and river type buffaloes has been reconfirmed based on microsatellite analyses (Zhang et al., 2007).

As concerns its natural distribution, one of the presumed ancestors of the domestic buffalo, Bubalus arnee is highly endangered (Hedges et al., 2008; Red List, http://www.iucnredlist.org) mostly because of high levels of hybridization with domestic populations, irrespective of the geographic region (Flamand et al., 2003).

While the African buffalo (Syncerus caffer) has never been domesticated and survived to dramatic ecological conditions over time (Heller et al., 2008), the Asian buffalo has occupied new territories as a result of domestication.

As concerns ecological distribution, the species accommodated in general to warm climates, from Eastern Asia to Mediterranean countries such Greece, Italy or Egypt, but also further north in the Balkans. The species has also been populated with real success in South America (Borghese, 2013) and Australia (Lemcke and Suarez, 2010). Within the distribution of the species, the Balkans 
and other European regions with small livestock seems to be the coldest climate where the species expanded naturally or artificially.

The heterogeneity of the species is relatively high in respect with morphological aspects and the majority of the populations were empirically bred over time, even nowadays. There are several described breeds or populations, mostly from India (Sethi, 2003; Moioli and Borghese, 2007) and Pakistan (Moioli and Borghese, 2007). In the Balkans, buffaloes were introduced many centuries ago (Velea et al., 1983) and they further evolved as a distinct population. We assume a within population reproduction over time, in spite of recent crossings with the Bulgarian Murrah breed. Although the Balkans hosted important livestock of buffaloes, the populations have been poorly studied or not studied at all from the perspective of genetic diversity.

In Romania, water buffaloes were firstly recorded in the $5^{\text {th }}$ century $\mathrm{BC}$ (Velea et al., 1983) and were mainly used for traction, milk and meat production. The selection, if any, was most probably done empirically, with few animal exchanges between neighbouring countries. From this perspective, the population evolved as a distinct and isolated population. In spite of centuries of evolution as a separate population, in the past decades, crossings have been performed with the Bulgarian Murah breed (from Bulgaria; Borghese, 2005) to improve milk production. But those crossings were only performed in a small fraction of the population, in the central part of Romania (Velea, personal communication). Within populations, some varieties have been described (Borghese, 2013) based on morphometric measurements, but the only certified classification is the one by Velea Constantin in 1987, when the Romanian Buffalo Breed was officially described and registered. In the same period, more than 200,000 animals were distributed all around Romania, some of the populations being valued for their high milk production. After the major political changes in 1989 in Romania, the buffalo livestock started to continuously decrease, most animals being sold for meat while others were exported. Nowadays, the livestock contains less than $10 \%$ of the population registered in 1989 , and breeding programs seem inexistent. The remaining population is mostly found in very small farms owned by old farmers, and the species needs urgent measures for being maintained at least.

In this general context, we tested the phylogenetic evolution of the Romanian buffalo breed based on cytochrome B complete gene. The motivation of the study was directly linked to the real extinction risk of this species in the region. Such a genetic study based on mitochondrial analysis could also provide the discovery of new haplotypes well adapted to the local climate considered atypical for the Mediterranean climate, where this ecotype of river buffalo prospered over time. Two questions have been addressed: I). Is the Romanian buffalo of Asiatic origin as it is supposed to be? and II). How diverse is the remaining population (based on $M T C Y B$ gene) of buffaloes?

\section{MATERIAL AND METHODS}

Biological samples

The selection of water buffalo (Bubalus bubalis) specimens was randomly performed, from 13 farms in Transylvania (Romania). Blood samples were taken in vacutainers containing EDTA anticoagulant. In total, we took blood samples from 52 individuals. From each individual, we collected $5 \mathrm{~mL}$ of blood from the jugular vein. Each blood sample was tagged with an internal code, and we recorded the sex, age and lactation of each animal. Vacutainers containing the collected blood were transported to the animal physiology laboratory and transferred into a freezer until DNA isolation.

\section{DNA isolation and Sequencing}

DNA isolation and PCR reaction were performed in a single step, by using Phusion Blood Direct PCR Kit (Thermo Fisher Scientific), directly from $1 \mu \mathrm{L}$ of blood. Amplification of the product was performed on BIORAD C-1000 thermo-cycler. Initial denaturation process was performed at $98^{\circ} \mathrm{C}$, followed by 40 cycles: denaturation at $98^{\circ} \mathrm{C}$, annealing at $53^{\circ} \mathrm{C}$ and elongation at $72^{\circ} \mathrm{C}$. Final elongation was performed at $72^{\circ} \mathrm{C}$ and final hold at $4^{\circ} \mathrm{C}$. The primers we used (Irwin et al., 1991; Su et al., 1999) were:

\begin{tabular}{ccc}
\hline 5' to 3' & bp & Primer sequence \\
\hline L14724 & 28 & CGAAGCTTGATATGAAAAACCATCGTTG \\
\hline H15915 & 28 & AACTGCAGTCATCTCCGGTTTACAAGAC \\
\hline
\end{tabular}


The PCR product sequencing was performed by Macrogen Europe by the standard procedure.

Phylogenetic analyses

The software used for sequences analyse and alignments was Geneious, version 6.0.6 (http://www.geneious.com). Homology of sequences was tested using BLAST application from NCBI (http://blast.ncbi.nlm.nih.gov/Blast.). The gene used in our study is mitochondrial Cytochrome $b$ gene (MTCYTB). We used the same software Geneious version 6.0.6 for phylogenetic tree building. We used Jukes-Cantor as genetic

Tab.1 Comparison sequences for mitochondrial Cytochome b gene in Bubablus bubalis

\begin{tabular}{|c|c|c|c|c|}
\hline No. & $\begin{array}{l}\text { Accession code } \\
\text { in GenBank }\end{array}$ & Name & Authors & County \\
\hline 1 & D88629.1 & $\begin{array}{l}\text { Bubalus bubalis mitochondrial DNA for } \\
\text { cytochrome b, complete cds }\end{array}$ & $\begin{array}{c}\text { Kikkawa,Y.,Yonekawa,H., Suzuki,H. and } \\
\text { Amano,T. }\end{array}$ & - \\
\hline 2 & EF409939.1 & $\begin{array}{c}\text { Bubalus bubalis haplotype } 1 \\
\text { cytochrome b (cytb) gene, partial cds; } \\
\text { mitochondrial }\end{array}$ & $\begin{array}{c}\text { Kumar,S., Nagarajan,M., Sandhu,J.S., } \\
\text { Kumar,N. and Behl,V. }\end{array}$ & India \\
\hline 3 & EF409940.1 & $\begin{array}{c}\text { Bubalus bubalis haplotype } 2 \\
\text { cytochrome b (cytb) gene, partial cds; } \\
\text { mitochondrial }\end{array}$ & $\begin{array}{c}\text { Kumar,S., Nagarajan,M., Sandhu,J.S., } \\
\text { Kumar,N. and Behl,V. }\end{array}$ & India \\
\hline 4 & EF409941.1 & $\begin{array}{c}\text { Bubalus bubalis haplotype } 3 \\
\text { cytochrome b (cytb) gene, partial cds; } \\
\text { mitochondrial }\end{array}$ & $\begin{array}{c}\text { Kumar,S., Nagarajan,M., Sandhu,J.S., } \\
\text { Kumar,N. and Behl,V. }\end{array}$ & India \\
\hline 5 & EF409942.1 & $\begin{array}{c}\text { Bubalus bubalis haplotype } 4 \\
\text { cytochrome b (cytb) gene, partial cds; } \\
\text { mitochondrial }\end{array}$ & $\begin{array}{c}\text { Kumar,S., Nagarajan,M., Sandhu,J.S., } \\
\text { Kumar,N. and Behl,V. }\end{array}$ & India \\
\hline 6 & FJ467648.1 & $\begin{array}{c}\text { Bubalus bubalis isolate GX24 } \\
\text { cytochrome b (cytb) gene, complete } \\
\text { cds; mitochondrial }\end{array}$ & $\begin{array}{l}\text { Lei,C.Z., Zhang,C.M., Weining,S., } \\
\text { Campana,M.G., Bower,M.A., Zhang,X.M., } \\
\text { Liu,L., Lan,X.Y. and Chen,H. }\end{array}$ & China \\
\hline 7 & JF946519.1 & $\begin{array}{c}\text { Bubalus bubalis haplotype NR-1 } \\
\text { cytochrome b gene, partial cds; } \\
\text { mitochondrial }\end{array}$ & $\begin{array}{c}\text { Saif,R., Babar,M.E., Hussain,T., Wajid,A., } \\
\text { Khan,W.A., Shah,S.A., Iqbal,F. and } \\
\text { Sabar,M.F. }\end{array}$ & Pakistan \\
\hline 8 & JF946520.1 & $\begin{array}{l}\text { Bubalus bubalis haplotype NR-2 } \\
\text { cytochrome b gene, partial cds; } \\
\text { mitochondrial }\end{array}$ & $\begin{array}{c}\text { Saif,R., Babar,M.E., Hussain,T., Wajid,A., } \\
\text { Khan,W.A., Shah,S.A., Iqbal,F. and } \\
\text { Sabar,M.F. }\end{array}$ & Pakistan \\
\hline 9 & JF946521.1 & $\begin{array}{l}\text { Bubalus bubalis haplotype NR-3 } \\
\text { cytochrome b gene, partial cds; } \\
\text { mitochondrial }\end{array}$ & $\begin{array}{c}\text { Saif,R., Babar,M.E., Hussain,T., Wajid,A., } \\
\text { Khan,W.A., Shah,S.A., Iqbal,F. and } \\
\text { Sabar,M.F. }\end{array}$ & Pakistan \\
\hline 10 & JF946522.1 & $\begin{array}{l}\text { Bubalus bubalis haplotype NR-4 } \\
\text { cytochrome b gene, partial cds; } \\
\text { mitochondrial }\end{array}$ & $\begin{array}{c}\text { Saif,R., Babar,M.E., Hussain,T., Wajid,A., } \\
\text { Khan,W.A., Shah,S.A., Iqbal,F. and } \\
\text { Sabar,M.F. }\end{array}$ & Pakistan \\
\hline 11 & JF946523.1 & $\begin{array}{c}\text { Bubalus bubalis haplotype NR-5 } \\
\text { cytochrome b gene, partial cds; } \\
\text { mitochondrial }\end{array}$ & $\begin{array}{c}\text { Saif,R., Babar,M.E., Hussain,T., Wajid,A., } \\
\text { Khan,W.A., Shah,S.A., Iqbal,F. and } \\
\text { Sabar,M.F. }\end{array}$ & Pakistan \\
\hline 12 & JF946524.1 & $\begin{array}{c}\text { Bubalus bubalis haplotype NR-6 } \\
\text { cytochrome b gene, partial cds; } \\
\text { mitochondrial }\end{array}$ & $\begin{array}{c}\text { Saif,R., Babar,M.E., Hussain,T., Wajid,A., } \\
\text { Khan,W.A., Shah,S.A., Iqbal,F. and } \\
\text { Sabar,M.F. }\end{array}$ & Pakistan \\
\hline 13 & JF946525.1 & $\begin{array}{c}\text { Bubalus bubalis haplotype NR-7 } \\
\text { cytochrome b gene, partial cds; } \\
\text { mitochondrial }\end{array}$ & $\begin{array}{c}\text { Saif,R., Babar,M.E., Hussain,T., Wajid,A., } \\
\text { Khan,W.A., Shah,S.A., Iqbal,F. and } \\
\text { Sabar,M.F. }\end{array}$ & Pakistan \\
\hline 14 & EF597571.1 & $\begin{array}{l}\text { Bubalus bubalis haplotype } \mathrm{R}-1 \\
\text { cytochrome b gene, complete cds; } \\
\text { mitochondrial }\end{array}$ & Zhang,Y., Sun,D.-X., Yu,Y. and Zhang,Y. & China \\
\hline
\end{tabular}


distance model, Neighbor-Joining tree built method and 1000 bootstrap replicates as resampling method. We computed Phylogeny Reconstruction using Minimum Evolution method as statistical analysis and Maximum Composite Likelihood as model, based on Close-Neighbor-Interchange (CNI) heuristic method as tree inference option in MEGA6 (Molecular Evolutionary Genetics Analysis) by Tamura et al. (2013).

For the comparison populations, we used 14 sequences (Table 1) of the same MTCYTB from GenBank used for similar studies. These sequences were from buffalo populations from Pakistan, India and China.

Bos taurus sequence (NC_006853) was used as an outgroup. Bayesian phylogenetic tree was constructed by MrBayes (Ronquist and Huelsenbeck, 2003) using the General Time Reversible (GTR) model with invariant site plus ten gamma categories. The Markov chain Monte Carlo (MCMC) chains were run for 100,000 and $1,000,000$ cycles. The tree construction was repeated three times.

\section{RESULTS AND DISCUSSION}

We have identified 5 new haplotypes in Romanian buffalo population (9.61\%). These have been uploaded in GenBank and named as Romanian Buffalo Breed from 1 to 5. Accession numbers were: Romanian Buffalo Breed 1 (RBB1), GenBank accession number: JQ241279; Romanian Buffalo Breed 2 (RBB2) GenBank accession number: JQ241280; Romanian Buffalo Breed 3 (RBB3) GenBank accession number: JQ241281; Romanian Buffalo Breed 4 (RBB4) GenBank accession number: JQ241282; Romanian Buffalo Breed 5 (RBB5) GenBank accession number: JQ241283. The rest of the samples were identical with haplotype 2 (EF409940.1) in percent of $36.54 \%$ and haplotype 3 (EF409941.1) respectively in percent of $53.85 \%$.

General Time Reversible (GTR) model and posterior output has generated a Bayesian computation tree in which the newly described haplotypes from Romanian buffalo population appear more closely related with the comparison

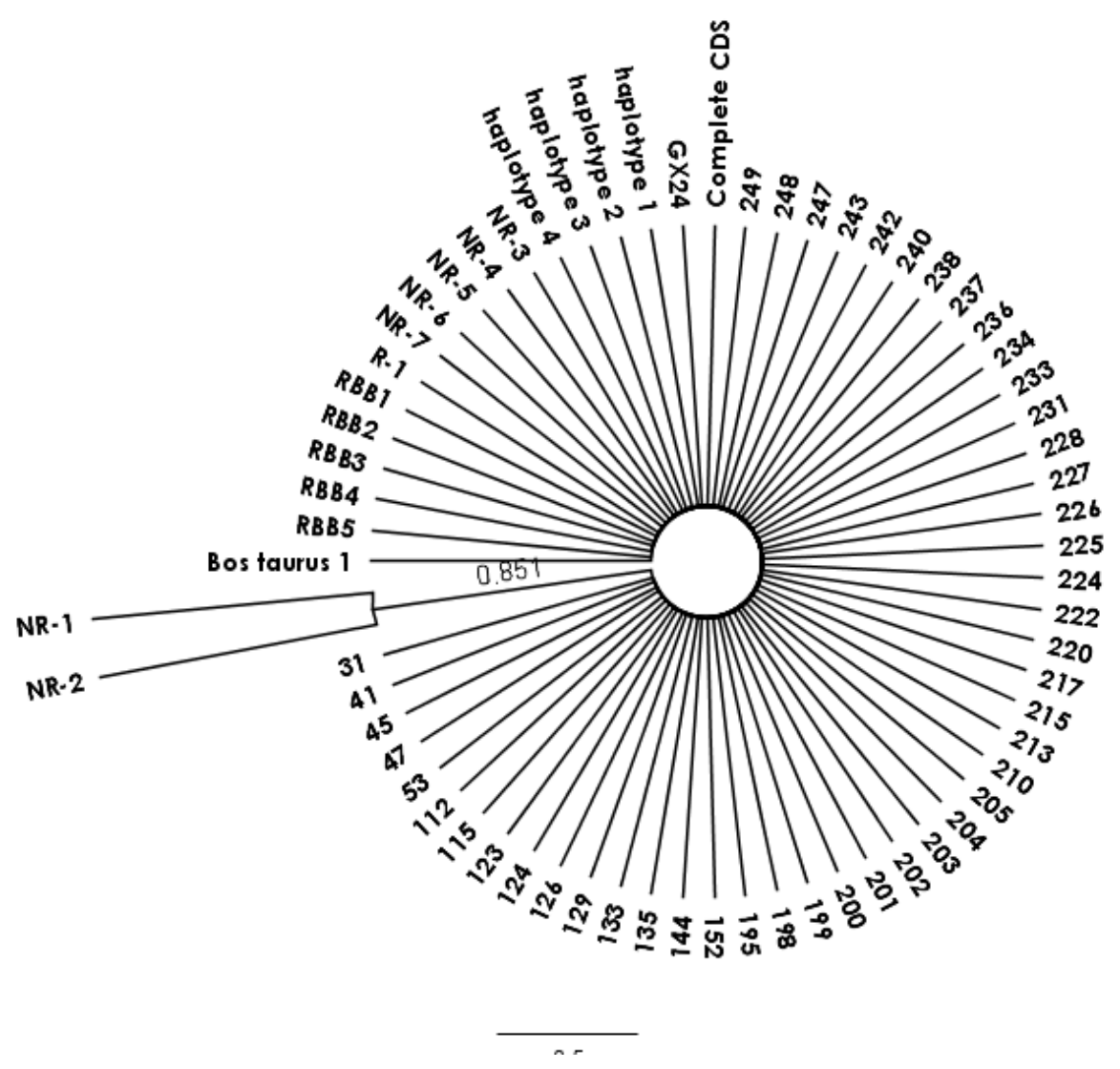

Fig. 1. Bayesian computation tree using General Time Reversible (GTR) model and 100,000 chain length. In total 52 samples of Romanian origin and 14 samples as comparison populations from India, Pakistan and China were used. The outgroup belonged to Bos taurus. 
sequence (Bos taurus) than any other sample (Figure 1). With the exception of two samples of Nili-Ravi breed from Pakistan which emerged from the others with a probability of 0.851 , the entire data set appeared as homogeneous. When the MCMC chains were run for $1,000,000$ cycles, the same pattern persisted with the only exception that four samples emerged separately: the same two samples of Nili-Ravi and one sample from India and one from China, the last ones with a posterior probability of 0.563 .

Neighbor-joining tree model and TamuraNei Genetic distance model with 1,000 bootstrap replicates grouped the data set into two major clades (Figure 2). The Romanian buffalo population grouped with 4 comparison samples, three of those from India and one from China. Once again, three of the newly described RBB haplotypes were more closely related with the outgroup sample.

One possible explanation here would be that some of the rare haplotypes, from Romanian buffaloes, belong to some common ancestors for the other populations. In spite of the generally accepted theory that domestication and migration of water buffaloes started from Southern Asia, it is not excluded that some of the maternal inherited populations simply disappeared from the original populations and survived in various other areas, which is the case of the Romanian buffaloes. Surely the possibility is not excluded that these haplotypes, if any, may not have been collected from the original populations due to a relatively small number of samples analysed to date. Another observation assumes that natural selection in the past one and a half millennia may have favoured some of the best adapted haplotypes in the Southern Carpathians climate, which is, according to our knowledge, the coldest reported region within the range of distribution of the species. We do not know how the buffalo livestock evolved on these territories, but they surely seemed to be well adapted, in spite of the colder and longer winters

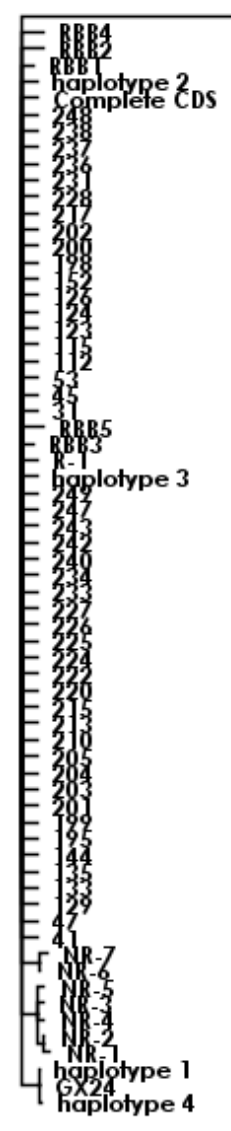

Bos taurus 1

Fig. 2. Neighbor-Joining tree based on 1000 bootstrap replicates. In total 52 samples of Romanian origin and 14 samples as comparison populations from India, Pakistan and China were used. The outgroup belonged to Bos taurus. 
compared to native ecological conditions. For this last scenario, more data and possibly also global meta-analyses are needed.

\section{CONCLUSION}

The Romanian buffalo is related with buffaloes of Asian origins. The highest similarity was observed with populations from India and Pakistan. In spite of the relatively low population size, 5 new haplotypes have been discovered. 47 out of 52 Romanian samples were identical with only two haplotypes described in Indian buffaloes, so the Romanian population appeared as relatively homogeneous. The new haplotypes have clustered with buffalo samples from Asia and they were the closest with the outgroup Bos taurus sample in both the Bayesian and the Neighbor-joining tree models. This mitochondrial phylogenetic analysis confirms the RBB's Asiatic origins. It has been also reconfirmed that the Mediterranean buffalo derived from Asian origin buffaloes. The presence of new haplotypes may also reflect the fact that this population is isolated from a geographical and reproductive point of view, but also heterogenic in terms of mitochondrial genotypes.

\section{REFERENCES}

1. Borghese A (2005). Buffalo production and Research. FAO Regional Office for Europe, REU. Technical Series 67:1315.

2. Borghese A (2013). In "Buffalo Livestock and Products". Ed. Borghese A. pages:1-493.

3. Flamand JRB, Vankan D, Gairhe KP, Duong H and Barker JSF (2003). Genetic identification of wild Asian water buffalo in Nepal. Animal Conservation 6: 265-270. doi:10.1017/ S1367943003003329.

4. Hedges S, Baral HS, Timmins RJ \& Duckworth JW (2008). Bubalus arnee. In: IUCN Red List of Threatened Species.
5. Heller R, Lorenzen ED, Okello JBA, Masembe C and Iegismund HRS (2008). Mid-Holocene decline in African buffalos inferred from Bayesian coalescent-based analyses of microsatellites and mitochondrial DNA. Molecular Ecology (2008) 17: 4845-4858.doi:10.1111/ j.1365-294X.2008.03961.x.

6. Irwin DM, Kocher TD and Wilson AC (1991).Evolution of the cytochrome b gene of mammals. J. Mol. Evol. 32:128144.

7. Kumar S, Nagarajan M, Sandhu JS, Kumar N, Behl V and Nishanth G (2007). Mitochondrial DNA analyses of Indian water buffalo support a distinct genetic origin of river and swamp buffalo. Animal Genetics 38: 227-232. doi:10.1111/j.1365-2052.2007.01602.x.

8. Lemcke B, Suarez M. (2010). Production Parameters from Different Breeds of Water Buffalo in Australia. Proceed. 9th World Buffalo Congress, Buenos Aires, Argentina, April 25-28. RevistaVeterinaria, 21 (suppl.1): 1046-1051.

9. Moioli B, Borghese A (2005). Buffalo breeds and Management systems. In Buffalo Production and Research, Ed. Antonio Borghese, FAO ReuTechinical Series 67: 51-76.

10. Ronquist $\mathrm{F}$ and Huelsenbeck JP (2003). MRBAYES 3: Bayesian phylogenetic inference under mixed models. Bioinformatics 19:1572-1574.

11. Sethi RK (2003). Buffalo Breeds in India. Proceed. 4th Asian Buffalo Congress, New Delhi, India, 25-28 Feb.

12. Su B, Wang Y-X, Lan H, Wang W and Zhang Y (1999). Phylogenetic Study of Complete Cytochrome b Genes in Musk Deer (Genus Moschus) Using Museum Samples. Molecular Phylogenetics and Evolution (12) 3: 241-249.

13. Tamura K, Stecher G, Peterson D, Filipski A, and Kumar S (2013). MEGA6: Molecular Evolutionary Genetics Analysis Version 6.0. Molecular Biology and Evolution 30: 2725-2729.

14. Velea C, Bud I and Tăpălagă A (1983).Creșterea bivolilor. Ed. Ceres, București.

15. Velea C, Mărginean G (2006). Actualitate și perspectivă în creșterea bubalinelor, Editura AgroTehnică, Bucureşti.

16. Zhang Y, Sun D, Yu Y and Zhang Y (2007). Genetic diversity and differentiation of Chinese domestic buffalo based on 30 microsatellite markers. Animal Genetics 38: 569-575. doi:10.1111/j.1365-2052.2007.01648.x 